\title{
Initial Career Motives and Demotivation in Teaching English as a Foreign Language: Cases of Korean EFL Teachers
}

\author{
TAe-Young KIM \\ YoOn-KYOUnG KIM \\ Chung-Ang University, South Korea
}

Received: 13 February 2014 / Accepted: 19 January 2015

ISBN: $1697-7467$

\begin{abstract}
In order to broaden understanding of English as a foreign language (EFL) teacher motivation, this study examines Korean EFL teachers' initial job motives and demotivating factors. Four psychological constructs emerged regarding initial career motives: Global Orientation, Job Security, Altruism, and Ought-to Self. Among the constructs, global orientation proved to be the most popular reason for choosing an EFL teaching career. This study also showed three constructs for detrimental factors on EFL teacher motivation: Obstacles to Communicative Language Teaching, Inadequate Administrative Support, and Lack of Social Recognition. It was shown that obstacles to communicative language teaching contributed to the greatest demotivation.
\end{abstract}

Keywords: EFL Teacher Motivation, Initial Career Motive, Demotivation, Global Orientation, Obstacles to Communicative Language Teaching.

Motivos trabajo inicial y la desmotivación en la enseñanza del inglés como lengua extranjera: Los casos de los profesores coreanos

RESUMEN: Para la comprensión de inglés como lengua extranjera (EFL) motivación del profesorado, este estudio examina motivos de trabajo inicial y factores desmotivadores de los profesores coreanos. Cuatro constructos psicológicos surgieron con respecto a los motivos de trabajo inicial: orientación global, seguridad en el empleo, altruismo, y Ought-to Self. Entre las constructos, orientación global resultó para ser la razón más popular para elegir una carrera de enseñanza de inglés como lengua extranjera. Este estudio también mostró tres constructos de factores perjudiciales en EFL motivación del profesorado: Los obstáculos de enseñanza comunicativa, la insuficiencia de apoyo administrativo, y la falta de reconocimiento social. Se ha demostrado que los obstáculos en enseñanza comunicativa ha contribuido a la mayor desmotivación.

Palabras claves: EFL profesor motivación, motivo de trabajo inicial, desmotivación, orientación global, obstáculos a la enseñanza de la lengua comunicativa.

\section{INTRODUCTION}

In successful second language (L2) learning, motivation of learners has been regarded as critical and therefore researched from various perspectives (e.g., Dörnyei \& Ushioda, 2009; Gardner, 2001; Kim, 2009, 2011, 2012; Norton, 2000). However, there has not been 
enough attention from the field of L2 motivation given to the motivation of L2 teachers. A higher level of teacher motivation is one of the important features for more effective education. In the field of education, there has been evidence that teacher-related factors influence learners (e.g., Curby, Rimm-Kaufman, \& Ponitz, 2009; Frenzel, Goetz, Lüdtke, \& Pekrun, 2009; Hinnant, O'Brien, \& Ghazarian, 2009). L2 teachers have also been reported to be related to students' L2 learning (Chambers, 1999; Kim \& Zhang, 2013). That is, English teachers play an important role in students' learning process and motivation, especially when the language is taught as an international language (McKay, 2002). For the ultimate goal of global communication with the target language, English teachers prepare diverse techniques and activities in order to facilitate practice of the target language and seek effective teaching practices to help L2 learners feel and stay motivated to learn it. In the process, the teachers' passion and eagerness into teaching might increase or decrease because of either internal or external reasons.

Given this, this study aims to investigate the nature of L2 teacher motivation. By focusing on the aspects of English teaching jobs and careers and building on the previous L2 teacher motivation research, initial career motives and demotivation of English as a foreign language (EFL) teachers in South Korea (henceforth Korea) are examined using a questionnaire survey. The survey results are then factor-analyzed in order to discover the features of the underlying structure of the participants' responses.

\section{Previous studies on L2 teacher motivation}

In general, knowledge of L2 teacher motivation is at a nescient stage. To date, L2 teacher motivation research has prevailed from the perspectives of jobs and careers. This section elaborates on how those types of studies have been conducted. Following this, we summarize the previous studies on the initial career motives of English teachers and demotivating factors on EFL teaching, which are the main focus of this study.

\subsection{L2 Teacher Motivation from the Perspective of the Job/Career Satisfaction}

Factors influencing L2 teachers' satisfaction with their job and career have been the most common focus of L2 teacher motivation research. By reviewing previous studies on work satisfaction and motivation of ESL teachers, Pennington (1995) showed that lack of career structure in the ESL teaching field negatively affected ESL teachers' satisfaction. She suggested the need for administration in the ESL field to set up work conditions that enable practitioners to perform at their highest possible level. She added that the conditions need to be aimed at satisfying their need for recognition by others and to allow them to realize their full potential.

Another examination of job and career satisfaction for L2 teaching was conducted by Kassabgy, Boraie, and Schmidt (2001). They surveyed teacher values, teaching rewards, and job/career satisfaction of 107 experienced EFL teachers in Egypt and ESL teachers in Hawaii. They found that the teachers regarded extrinsic values as less important than intrinsic ones, and that ESL/EFL teaching provided more intrinsic rewards than extrinsic. More detailed characteristics of teacher values (i.e., what teachers think is important for their job/career) and teaching rewards (i.e., what teachers think makes teaching a good job) were revealed 
through factor analysis. It was reported that five factors emerged from values, which were a relationship orientation, extrinsic motivation, autonomy needs, a self-realization factor, and institutional support needs. Teaching rewards were categorized into four factors: good management, a professional position, one's students, and a challenging job. In addition, their study attempted to validate Herzberg's (1968) Dual Structure Hypothesis, which predicted that the motivational factors intrinsic to the work itself contribute to satisfaction, while extrinsic ones determine dissatisfaction. However, Kassabgy et al. failed to support the hypothesis, in that individual teachers chose both intrinsic and extrinsic reasons for both satisfaction and dissatisfaction with their job and career. Therefore, those reasons, or motivations, did not relate to just one end of the satisfaction and dissatisfaction continuum.

\subsection{Initial Career Motives of $\mathbf{L} 2$ Teachers}

As an initial stage of L2 teacher motivation, the career choice to be an English teacher has been investigated. Igawa (2009) analyzed English teachers' initial motive to choose their profession in Japan, Cambodia, and the U.S. In order to generate a list of possible reasons why teachers chose to teach English, 27 Japanese EFL teachers were asked to respond to an open-ended question regarding their initial professional motive. Thirteen categories were established by organizing their responses. From the thirteen categories, 49 Cambodian EFL and 34 U.S. ESL teachers were required to choose the three most valued reasons for becoming English teachers.

The study results indicated that more than half of the English instructors in Japan decided to be English teachers because of their enthusiasm toward English (51.9\%). The Japanese teachers' second most favored motive was concerned with women-friendliness of the occupation (18.5\%). According to Igawa (2009), "this reflects not only the fact that female teachers comprise the majority" in the Japanese sample $(77.8 \%)$ "but also the job availability of the time when these female teachers were job-hunting in Japan" (p. 212). This aspect was explained to be related to the respondents' parents because "parents recommended the job for their daughters largely due to the fact that it was one of the few jobs that were women-friendly" (p. 213). English teachers in Cambodia chose categories related to intrinsic motives such as 'I liked teaching' (40.8\%) and 'I liked English' (36.7\%) as the most and the third most popular reasons. Willingness to contribute to society was the second most popular reason $(38.8 \%)$.

Among U.S. ESL teachers, the item 'Other' was identified as the most popular reason (52.9\%). The item was the one included to identify other reasons for becoming an English teacher besides the given questionnaire items. There was an open-ended column for those who choose this item to write the reason. The detailed other reasons in the U.S. sample were 'to travel abroad,' 'to live abroad,' 'interests in foreign culture and people,' 'to study foreign languages and linguistics,' 'free time,' 'money,' and 'talented as a teacher.' Igawa stated that the fact that the item 'Other' was the U.S. teachers' most popular reason shows "the limitation of using the tool developed from the responses of the non-native speaking teacher group on native speaking teachers" (p. 220). He suggested that these items should be added to the original instrument for a more comprehensive examination. 


\subsection{L2 Teacher Demotivation}

Demotivation of L2 teachers is also one of the new areas in the field of L2 motivation. In that respect, Sugino's (2010) research on L2 teacher demotivation was guided by previous studies on demotivating factors for teachers in general (e.g., Bennell, 2004; Kiziltepe, 2008). For example, Bennell (2004) focused on the material and psychological need of teachers in sub-Sahara Africa and Asia. Bennell noted that in many of these countries, low level of motivation of public school teachers arose from a combination of low morale and job satisfaction, poor incentives, and inadequate controls and other behavioral sanctions. In Kiziltepe's (2008) study, demotivating factors was categorized into five factors: students, economics, structural and physical characteristics, research, and working conditions. Student-related factors were found to be the main source of motivation and demotivation for university teachers.

Reflecting on the above-stated studies, Sugino (2010) conducted research into what aspects demotivate English instructors in Japan. For this purpose, he implemented a questionnaire with 37 items categorized into four demotivating factors: students' attitudes, students' abilities and school facilities, working conditions, and human relationships. The study participants were 97 English teachers working in Japanese universities. The first language of most participants (77.5\%) was Japanese, while 21 (19.1\%) used English, one French, one Vietnamese, one Portuguese, and one Korean. The descriptive results showed that students' negative attitudes or behaviors were recognized as being the most demotivating factor, with five out of the top seven factors related to student attitudes. The least-frequently responded items were associated with teaching material and discrepancy in student abilities.

Despite the above literature, few studies have accounted for the unique nature of English teacher motivation. Specifically, the internal structure of initial career motive and demotivation has not been fully investigated, especially in the contexts of elementary and secondary school. Therefore, this study expands on the studies described above by exploring the initial phase of L2 teacher motivation or initial career motives, and the factors negatively affecting L2 teacher motivation. For this purpose, the following two research questions were postulated:

1. What are the features of Korean EFL teachers' initial career motives?

2. Which factors have negative effects on their EFL teaching motivation?

\section{Methodology}

\subsection{Participants}

A total number of 94 in-service EFL teachers participated in the survey: 51 elementary school teachers (54\%) and 43 secondary school teachers (46\%). The age of participants ranged from 24 to 60 . Female teachers accounted for $78 \%$ of participants. On average, the participating secondary school teachers had 19 years of experience in teaching English. The elemenraty school teachers had 8 and half a years of experience in teaching, and the mean years of experience in teaching English was three years and four months. Among elementary school teachers, there is difference between the years of experience for teaching and for teaching English because English teaching in elementary schools began in 1997; some 
teachers had taught general elementary school subjects such as Korean, math, social science, and so on, and then swithced to teach English sometime after 1997.

\subsection{Data Collection}

This study adopted questionnaire survey methods to investigate initial career motives and demotivating factors of Korean teachers of English (see Appendix). The questionnaire was administered during two teacher training workshops: one for elementary school English teachers held in November 2011 and the other for secondary school English teachers in January 2012.

The first section of the questionnaire asked why the teachers chose to teach English. Based on Igawa's (2009) study, 18 items were generated for initial career motives. An openended question was added asking if there was another reason for choosing an EFL career or job in addition to the items given in the questionnaire. The second section included nine items concerning the potential factors negatively affecting EFL teaching motivation. Those items were developed in reference to the factors leading to dissatisfaction with job and career aspects included in Pennington's (1995) and Kassabgy et al.'s (2001) studies and the demotivating factors considered in Sugino's (2010) study. An open-ended question was also added for additional factors influencing EFL teaching motivation. All of the items were measured by a five-point, Likert-type scale, ranging from disagree strongly (1) to agree strongly (5).

\subsection{Data Analysis Method}

The collected data were analyzed using SPSS 18.0. The items asking the reasons for initial career motives and demotivating factors were respectively factor-analyzed to discover the nature of the underlying structure of the items and to examine their internal reliabilities. Descriptive analysis was used to display the mean and standard deviation of the factors of initial career motives and demotivating factors.

\section{Results AND Discussion}

\subsection{Initial Career Motive of English Teachers}

From the questionnaire items on initial career motives, as shown in Table 1, four factors emerged, accounting for approximately $64 \%$ of the variance. Factor 1 includes seven items $(\alpha=.873)$, which is labeled as Global Orientation. This factor exhibits EFL teachers' initial enthusiasm for teaching and using English as a global language. To be specific, the items in Factor 1 indicate that EFL teachers desired encounters and communication with people from all over the world. They also hoped to help their students develop the same wishes and help them to realize those wishes by teaching English.

This concept may seem similar to international posture by Yashima $(2002,2009)$ as both are concerned with the current status of English as an international language. International posture includes interest in foreign or international affairs, willingness to go overseas to stay or work, readiness to interact with intercultural partners, and openness toward different 
cultures. Considering the expressions of interest, willingness, readiness, and openness above, international posture can be an unclear expectation that L2 learners come up with in relation to their L2 learning. Such expectation allows L2 learners to think they can do something by learning English even though it is not clear to them exactly what that is. Given this, although international posture may well cover a positive tendency or predisposition toward globalization in learning English, it seems that the term may not sufficiently explain all items in Factor 1. The items in Factor 1 exhibit EFL teachers' sense of purpose: they believed that it was significant to teach English in an era of globalization, and therefore they chose an EFL teaching career.

Table 1. Factors for English Teachers' Initial Career Motive

\begin{tabular}{cccccccc}
\hline \multicolumn{2}{c}{$\begin{array}{c}\text { Factor 1: } \\
\text { Global Orientation }\end{array}$} & \multicolumn{2}{c}{$\begin{array}{c}\text { Factor 2: } \\
\text { Job Security }\end{array}$} & \multicolumn{2}{c}{$\begin{array}{c}\text { Factor 3: } \\
\text { Altruism }\end{array}$} & \multicolumn{2}{c}{$\begin{array}{c}\text { Factor 4: } \\
\text { Ought-to Self }\end{array}$} \\
\hline \multirow{2}{*}{ Item } & Factor & Item & Factor & Factor & Foctor \\
& Loading & & Loading & & Loading & & Loading \\
\hline 17 & .895 & 14 & .798 & 2 & .835 & 1 & .744 \\
4 & .849 & 15 & .766 & 8 & .793 & 3 & .652 \\
18 & .827 & 16 & .652 & 6 & .716 & 9 & .585 \\
5 & .674 & 7 & .611 & 13 & .575 & & - \\
10 & .610 & - & - & - & - & - & - \\
11 & .509 & - & - & - & - & - & - \\
12 & .488 & - & - & - & - & - & - \\
\hline
\end{tabular}

The factor of global orientation also involves L2 teacher' ideal L2 self. The ideal L2 self is one of the components in Dörnyei's $(2005,2009)$ L2 motivational self system. This framework focuses on aspects of the individual's self, especially the individual's future self-images regarding L2 learning and use. Dörnyei (2009) stated that "language learning is a sustained and often tedious process with lots of temporary ups and downs" and in this process, the secret of successful learners seems to be "their possession of a superordinate vision that kept them on track" (p. 25). Influenced by this idea on imagery and vision, the ideal L2 self refers to the future self-image that one would like to achieve by learning an L2. This L2 self is suggested to be a powerful motivator to learn an L2 when one recognizes the gap between her/his actual self and the ideal self and tries to reduce the gap between them. Looking at the items in Factor 1, the use and teaching of English were perceived as meaningful activity by English teachers and they connected this aspect to their ideal, future L2 self. That is, Korean EFL teachers' ideal self is identified as someone who is a fluent English speaker, and also someone who is competent in teaching English in this era of globalization. This ideal self of English teachers is formed and developed in an imagined 
community (Wenger, 1998) in that this community is realized through occupational means or communication with English speakers, and in all cases, the use of L2 is supported. In this regard, Factor 1 shows teachers' desire to participate in their imagined community to fulfill their ideal L2 self.

The items loaded on Factor $2(\alpha=.721)$ represent Job Security. Factor 2 features both extrinsic and intrinsic facets of EFL teachers' initial career motives. By reviewing the works on intrinsic-extrinsic distinction, Cooman et al. (2007) explained that intrinsic job motives have been described as being concerned with characteristics of the job itself and extrinsic job motives as being connected to externally initiated behavior. Factor 2 in this study, on one hand, demonstrates an extrinsic motive in that teachers considered the stability of an EFL teaching job in their career choice. Pursuing a stable job is made possible from the external influences. At the same time, this factor shows that the teachers decided to be English teachers because it is suitable for them. This aspect arises from an intrinsic motive because it is directly relevant to the activity of teaching itself (Kanungo \& Hartwick, 1987). Kassabgy et al.'s (2001) study showed that it is inappropriate to explain English teacher motivation with the complete separation of extrinsic/intrinsic aspects. Also, in this study, intrinsic and extrinsic aspects are involved in the same factor. Accordingly, it is suggested that researching L2 teacher motivation needs to explore the complexity and possible combination of extrinsic and intrinsic L2 teacher motivation, not solely based on the distinction between the two.

Factor 3 is Altruism $(\alpha=.751)$, which represents teaching English as directed at the goodness of, and interest in, others. Altruistic motives for choosing a career in teaching have been demonstrated by several studies (Bastick, 2000; Cooman, Gieter, Pepermans, Bois, Caers, \& Jegers, 2007; Yong, 1995). That is, this type of motive is not limited to the case of English teachers. For example, Cooman et al. (2007) found altruistic features were a strong job-specific motive from the responses of 241 recently graduated teachers in Flanders, Belgium. Specifically, they compared teachers and non-teachers' work values. Both groups were the graduates of nine different teacher training institutes in Flanders, but some held a teaching job and others held a non-teaching job. It was determined that while the teacher group preferred altruistic work values, the non-teacher group were more attracted by individualistic work values such as career opportunities.

Factor 4, which includes three items $(\alpha=.580)$, is labeled as Ought-to Self, derived from the concept of ought-to L2 self by Dörnyei $(2005,2009)^{1}$. Included in the L2 motivational self system, the ought-to L2 self refers to what one feels they ought to possess in learning an L2. This L2 self is developed by duties or responsibility and also avoidance of possible negative outcomes in learning English. For example, students might think that studying English is important because other people, including their parents, say they should learn it. Also, students may be feeling that they have to study English because they do not want to get a poor score at school or be considered a poorly educated person. The items in Factor 4 show that, for several English teachers, parental recommendation and their disappointment mattered when they chose an English teaching career. They also wanted to avoid negative outcomes from pursuing a career other than teaching English. Therefore, Factor 4 exhibits the initial career motives caused by a sense of obligation and fear for negative consequences and can be designated as ought-to self.

\footnotetext{
${ }^{1}$ The term of 'L2' is not included in designating initial career motive of English teachers because this motive does not seem to be directly related to the L2, but rather to job and career as teachers.
} 
In summary, the four factors for initial career motives of Korean EFL teachers are global orientation, job security, altruism, and ought-to self. In Table 2, the factors were presented in order from the most frequently responded to the least. The most popular reason for choosing to teach English was global orientation. Altruism and job security also played an important role in EFL teachers' professional choice, with mean scores more than the 3.0 neutral point. Ought-to self were rated lower than the 3.0 neutral point, suggesting that this construct did not serve as a strong motive for initial career choice.

Table 2. Descriptive Statistics for Initial Career Motives

\begin{tabular}{lcccc}
\hline & Min. & Max. & M & SD \\
\hline Global Orientation & 1.57 & 5.00 & 3.88 & .80 \\
Altruism & 1.75 & 5.00 & 3.69 & .68 \\
Job Security & 1.00 & 5.00 & 3.27 & .86 \\
Ought-to Self & 1.00 & 5.00 & 2.73 & .89 \\
\hline
\end{tabular}

NOTE. The minimum values should ideally be 1.00 . However, minimum values are mean scores of the items belonging to the same construct. If the value is 1.00 , this means that at least one participant responded all items in a construct in "disagree strongly."

Global orientation, which was the most decisive initial career motive, is considered reflective of the distinctive feature of EFL teaching profession. Choosing a teaching profession in general has often been described with the extrinsic, intrinsic, and altruistic (EIA) factor model (Bastick, 2000; Yong, 1995). For example, Bastick (2000) examined the motives of 1,444 Jamaican pre-service teachers for choosing the teaching profession. He first conducted semi-structured interviews with 96 student teachers and small focus groups with 30 other student teachers to find the most popular reasons that pre-service teachers joined the profession. Those data were coalesced into 19 most prevalent reasons, and then an island-wide survey in Jamaica was carried out based on those most prevalent reasons. The next stage was exploratory factor analysis of the survey data to test the veracity of the EIA (Extrinsic, Intrinsic, Altruistic) factor model for describing those reasons. He, finally, proved that extrinsic, intrinsic and altruistic considerations were three distinct initial career motives for the pre-service teachers. Even studies on English teachers' initial career motives have been based on two or three considerations in the EIA model (Igawa, 2009; Kassabgy et al., 2001). However, it is suggested that career choice for EFL teaching is associated with the current nature of the English language. The language is used and taught as an international language to communicate with people from all over the world (McKay, 2002). The items making up the global orientation factor showed how important L2 teachers believe it is to teach English in a globalized world, and how interested they were in foreign cultures and people. Given this, we argue that the awareness of globalization has great relevance to English teacher motivation. 


\subsection{Demotivation on EFL Teaching}

As the first step for delving into negative impacts on EFL teaching motivation, the demotivational items were factor-analyzed. As presented in Table 3, three factors were identified, accounting for approximately $57 \%$ of the variance in the data. Cronbach's alpha indexes were $\alpha=.605$ for Factor $1, \alpha=.657$ for Factor 2, and $\alpha=.528$ for Factor 3.

Table 3. Factors for Demotivation on EFL Teaching

\begin{tabular}{cccccc}
\hline $\begin{array}{c}\text { Factor 1: Obstacles to } \\
\begin{array}{c}\text { Communicative Language } \\
\text { Teaching }\end{array}\end{array}$ & $\begin{array}{c}\text { Factor 2: Inadequate } \\
\text { Administrative Support }\end{array}$ & \multicolumn{2}{c}{$\begin{array}{c}\text { Factor 3: } \\
\text { Lack of Social Recognition }\end{array}$} \\
\hline \multirow{2}{*}{ Item } & Factor & Factor & Item & Factor \\
& Loading & Item & Loading & & Loading \\
\hline 5 & .790 & 6 & .875 & 3 & .739 \\
7 & .698 & 4 & .731 & 9 & .662 \\
8 & .535 & 2 & .533 & 1 & .658 \\
\hline
\end{tabular}

Factor 1, representing Obstacles to Communicative Language Teaching, indicates that EFL teaching can be demotivating when the teachers have difficulties in teaching English in communicative ways. It should be noted that the obstacles mentioned in Factor 1 are related to the characteristics of EFL teaching. In other words, the difficulties English teachers face are closely associated with the fact that the ultimate goal of teaching and learning English is primarily global communication (Wallace, 1991). To reach this goal, English teachers prepare diverse techniques and activities in order to encourage learners' active participation and help them effectively practice the target language. If students seem to lethargically or unenthusiastically react to the teachers' efforts toward this objective, EFL teachers are likely to feel their teaching practices are not useful. For example, Hwang, Seo and Kim (2010) reported the frustration of an EFL teacher who tried to lead L2-only class to facilitate students' L2 communication. The teacher found that students continuously responded in the first language (L1) in spite of his reiterative attempts. This made the teacher think that he had failed to manage the class. In the end, he decided to regress back to L1 instead of using only L2. Also, interaction between teachers and students in a variety of ways is important for communication in the target language. Too many students in a language class and limited chances for autonomous teacher-student practice may hinder EFL teachers' communicative approach to L2 learning and teaching. In Korea, the average number of students per class in elementary school is 25.5, and around 33 in secondary school; 33 in junior school and 33.1 in high school (Ministry of Education, Science, \& Technology, 2011). The participating EFL teachers seem to find this number of students in a language class to be rather large, making it difficult to lead the class toward the goal of global communication.

In line with this, it is likely that EFL teachers' initial career motive from global orientation comes in conflict with obstacles to communicative language teaching. Global orientation 
was the strongest motive for EFL career choice as demonstrated earlier. This orientation shows that English teachers chose their career because they believed it was wonderful and enjoyable to teach English for international communication in a globalized world. However, the difficulties unique to teaching English in a communicative way described above can work against teaching with this belief. This is when the obstacles to communicative language teaching can negatively affect EFL teaching motivation.

Three items fell into Factor 2, which is designated as Inadequate Administrative Support. This factor exhibits that EFL teaching motivation may well decrease when they find that administrative circumstances at school, including their colleagues, are not seen as adequately supportive. This lack of administrative support for EFL teachers includes a heavy workload besides teaching. This type of burden has been suggested to have negative impacts on English teaching quality (e.g., Marwan, 2009; Sugino, 2010). Marwan (2009) conducted research into the workload of six English teachers working full time at an Indonesian vocational university. With the semi-structured interview method, he found that the participants experienced difficulty in applying good EFL teaching practices because of their heavy workload, suggesting its negative influence on EFL teaching quality.

Factor 3 includes three items, indicating that EFL teaching demotivation can be caused by Lack of Social Recognition. This factor denotes that teachers care about the recognition or respect which they can achieve from their work. In the case of EFL teachers, however, this desired recognition from school and parents is more related to recognition for English teaching competence. Tsui (2007) conducted a narrative inquiry into an individual's experience as an EFL teacher in order to look into the teacher's identity formation. By examining how the participant formed his identity as an effective teacher, Tsui found that the recognition of teachers' competence in EFL teaching affected forming that identity. Conversely, when teachers feel that their ability in EFL teaching is not rightly appreciated, they can be demotivated. Given this, the aspects of EFL teaching mentioned in this factor are likely perceived by English teachers as the sources leading to low morale and self-esteem, and a detrimental effect on EFL teaching motivation.

Table 4. Descriptive Statistics for Demotivation

\begin{tabular}{lcccc}
\hline & Min. & Max. & M & SD \\
\hline $\begin{array}{l}\text { Obstacles to Communicative Language } \\
\text { Teaching }\end{array}$ & 2.00 & 5.00 & 3.81 & .76 \\
Inadequate Administrative Support & 1.33 & 5.00 & 3.55 & .75 \\
Lack of Social Recognition & 1.33 & 5.00 & 3.32 & .75 \\
\hline
\end{tabular}

NOTE. The minimum values of all of the three constructs are more than 1.00 for the same reason explained in Table 2.

In the second step of looking into demotivating factors on EFL teaching, the three relevant constructs were analyzed to identify which factor EFL teachers find most detrimental on their teaching motivation. Table 4 displays the construct of obstacles to communicative language teaching that most highly brought about demotivation among the Korean EFL 
teachers. As described earlier, the construct shows that what teachers regard as a negative impact on motivation is mainly concerned with the feature of teaching English communicatively. This aspect points to the need to understand EFL teaching motivation within its characteristics, such as teaching global language and communicative objectives. Also, with mean scores higher than the 3.0 neutral point, the other two constructs were identified as predictably demotivating factors among English teachers in Korea.

\subsection{Open-Ended Questions in Initial Career Motives and Demotivating Factors}

The questionnaire in this study contained two open-ended questions asking about any other initial career motives or demotivating factors besides the given items. First, two elementary school English teachers had a common response on their reason for becoming an English teacher. They reported that they were assigned to teach English by the school's demand, which reflects a situation unique to English education in Korean elementary schools. English teaching in elementary school began in 1997, and not all of the English teachers in elementary schools started their career as English teachers. In some cases, elementary school teachers who were in charge of general elementary education were asked to teach English by their schools. These two participants are examples of this case.

From the responses regarding any other demotivating factor, a common point was concerned with students. Three teachers found it frustrating to teach students with a large gap in English proficiency in the same class or students with a low level of motivation. It indicates that student-related factors have an impact on L2 teacher motivation. Chambers (1999) demonstrated that among various factors, students' positive or negative appraisal of L2 learning significantly contributed to the teacher motivation. In this sense, this study verifies the basic assumption in terms of L2 teacher motivation and L2 learning motivation that exert mutual influences (Dörnyei \& Ushioda, 2011).

\section{ImPLiCATIONS}

Based on the research findings, practical implications can be suggested for language teacher development. In the field of L2 teacher education, teacher belief about effective language learning and teaching has come to the foreground of teacher educators' attention (e.g., Borg, 2011; Peacock, 2001; Phipps \& Borg, 2009; Zeng \& Murphy, 2007). For example, Borg (2011) suggested the ways to encourage L2 teachers in teacher education programs to examine their beliefs in order to develop helpful ones for their teaching practices. In this study, the stronger initial career motive of English teachers demonstrated their belief that it is significant to teach English for international communication in a globalized world (i.e., global orientation). Likewise, initial career motives seem to have played a part in the formation of teacher belief. Thus, it is recommendable that teacher education programs include reflection on why L2 teachers chose to teach the target language in allowing them to examine their belief about language learning and teaching. This would contribute to a deeper understanding of teachers' own beliefs.

Also, in addition to teachers' reflection on belief and teaching practices, this study suggests that it is necessary for teacher education programs to focus more on the affective 
aspects of language teachers. That is, this study denoted potentially detrimental factors for EFL teachers' motivation or enthusiasm for teaching English. In order to achieve more successful teacher development, teachers need to be provided with opportunities to share those difficulties that they face in L2 teaching and attempt to come up with appropriate solutions for the problems.

Furthermore, the findings of this study provide important perspectives for researching EFL teacher motivation. First, dissatisfaction related to initial career motive is a potential detriment to EFL teaching as is the case between global orientation and the obstacles to communicative language teaching. More in-depth investigations into it can show, in what way, which demotivating factors inhibit initial career motives from leading to positive effects on English teacher motivation. Similarly, it is suggested to examine if and how teachers' satisfaction with their initial career motives is positively transformed into a high level of motivation, leading to more effective teaching performance.

\section{REFERENCES}

Bastick, T. (2000). "Why teacher trainees choose the teaching profession: Comparing trainees in metropolitan and developing countries", in International Review of Education, 46: 343-349.

Bennell, P. (2004). Teacher motivation and incentives in sub-Saharan Africa and Asia. Brighton, UK: Knowledge and Skills for Development.

Borg, S. (2011). "The impact of in-service teacher education on language teachers' beliefs", in System, 39: 370-380.

Chambers, G. N. (1999). Motivating language learners. Clevedon, UK: Multilingual Matters.

Cooman, R., Gieter, S., Pepermans, R., Bois, C., Caers, R. and Jegers, M. (2007). "Graduate teacher motivation for choosing a job in education", in International Journal for Educational and Vocational Guidance, 7: 123-136.

Curby, T. W., Rimm-Kaufman, S. E. and Ponitz, C. C. (2009). "Teacher-child interactions and children's achievement trajectories across kindergarten and first grade", in Journal of Educational Psychology, 101: 912-925.

Dörnyei, Z. (2005). The psychology of the language learner: Individual differences in second language acquisition. Mahwah, NJ: Lawrence Erlbaum.

Dörnyei, Z. (2009). "The L2 motivational self system", in Z. Dörnyei and E. Ushioda (eds.), Motivation, language identity and the L2 self. Bristol, UK: Multilingual Matters, 9-42.

Dörnyei, Z. and Ushioda, E. (eds.) (2009). Motivation, language identity and the L2 self. Bristol, UK: Multilingual Matters.

Dörnyei, Z. and Ushioda, E. (2011). Teaching and researching motivation (2nd ed.). Harlow, UK: Longman.

Frenzel, A. C., Goetz, T., Lüdtke, O. and Pekrun, R. (2009). "Emotional transmission in the classroom: Exploring the relationship between teacher and student enjoyment", in Journal of Educational Psychology, 101: 705-716.

Gardner, R. C. (2001). "Integrative motivation and second language acquisition", in Z. Dörnyei and R. Schmidt (eds.), Motivation and second language acquisition. Honolulu, HI: University of Hawaii Press, 1-20.

Herzberg, F. (1968). "One more time: How do you motivate employees?", in Harvard Business Review, 46: 53-62. 
Hinnant, J. B., O'Brien, M. and Ghazarian, S. R. (2009). "The longitudinal relations of teacher expectations to achievement in the early school years", in Journal of Educational Psychology, 101: 662-670.

Hwang, S.-S., Seo, H.-S., and Kim, T.-Y. (2010). "Korean English teachers' disempowerment in English-only classes: A case study focusing on Korea-specific cultural aspects", in The Sociolinguistic Journal of Korea, 18: 105-135.

Igawa, K. (2009). "Initial career motivation of English teachers: Why did they choose to teach English?", in Shitennoji University Bulletin, 48: 201-226.

Kassabgy, O., Boraie, D. and Schmidt, R. (2001). "Values, rewards, and job satisfaction in ESL/ EFL", in Z. Dörnyei and R. Schmidt (eds.), Motivation and second language acquisition. Honolulu, HI: University of Hawaii Press, 213-237.

Kim, T.-Y. (2009). "The sociocultural interface between ideal self and ought-to self: A case study of two Korean students' ESL motivation", in Z. Dörnyei and E. Ushioda (eds.), Motivation, language identity and the L2 self. Bristol, UK: Multilingual Matters, 248-273.

Kim, T.-Y. (2011). "Sociocultural dynamics of ESL learning (de)motivation: An activity theory analysis of two adult Korean immigtants", in The Canadian Modern Language Review, 67: 91-122.

Kim, T.-Y. (2012). "The L2 motivational self system of Korean EFL students: Cross-grade survey analysis", in English Teaching, 67: 29-56.

Kim, T.-Y., and Zhang, Q.-M. (2013). "Research on second language teacher motivation: From a Vygotskian activity theory perspective", in The SNU Journal of Eduation Research, 22: 1-29.

Kiziltepe, Z. (2008). "Motivation and demotivation of university teachers", in Teacher and Teaching: Theory and Practice, 14: 515-530.

Marwan, A. (2009). "Teachers' workload and EFL teaching quality”, in Singapore Tertiary English Teachers Society (STETS) Language \& Communication Review, 8: 31-35.

Ministry of Education, Science and Technology. (2011). Brief statistics on Korean education. Retrieved February 17, 2012 from http://cesi.kedi.re.kr/publ/P_SP_BS_XX_0001.jsp.

McKay, S. (2002). Teaching English as an international language. Oxford, UK: Oxford University Press.

Norton, B. (2000). Identity and language learning: Gender, ethnicity and educational change. Harlow, UK: Pearson.

Peacock, M. (2001). "Pre-service ESL teachers' beliefs about second language learning: A longitudinal study", in System, 29: 177-195.

Pennington, M. C. (1995). Work satisfaction, motivation and commitment in teaching English as a second language. ERIC Document ED 404850.

Phipps, S., and Borg, S. (2009). "Exploring tensions between teachers' grammar teaching beliefs and practices", in System, 37: 380-390.

Sugino, T. (2010). "Teacher demotivational factors in the Japanese language teaching context", in Procedia - Social and Behavioral Sciences, 3: 216-226

Tsui, A. B. M. (2007). "Complexities of identity formation: A narrative inquiry of an EFL teacher", in TESOL Quarterly, 41: 657-680.

Wallace, M. (1991). Training foreign language teachers: A reflective approach. Cambridge, UK: Cambridge University Press.

Wenger, E. (1998). Communities of practice: Learning, meaning, and identity. Cambridge, UK: Cambridge University Press.

Yashima, T. (2002). "Willingness to communicate in a second language: The Japanese EFL context", in The Modern Language Journal, 86: 54-66. 
Yashima, T. (2009). "International posture and the ideal L2 self in the Japanese EFL context", in Z. Dörnyei and E. Ushioda (eds.), Motivation, language identity and the L2 self. Bristol, UK: Multilingual Matters, 144-163.

Yong, B. (1995). “Teacher trainees' motives for entering into a teaching career in Brunei Darussalam", in Teaching \& Teacher Education, 11: 275-280.

Zeng, Z. and Murphy, E. (2007). "Tensions in the language learning experiences and beliefs of Chinese teachers of English as a foreign language", in TESL-EJ, 10. Retrieved 1 May 2013 from http://www.tesl-ej.org/wordpress/issues/volume10/ej40/ej40a1/ 


\section{APPENDIX \\ Questionnaire Items on EFL Teachers' Intial Career Motives and Demotivation}

\section{Initial Career Motive}

\begin{tabular}{|c|c|c|}
\hline & No & Item \\
\hline \multirow{7}{*}{ Factor 1} & 17 & $\begin{array}{l}\text { I thought I could meet a lot of different people around the world through } \\
\text { English. }\end{array}$ \\
\hline & 4 & I thought it was wonderful to communicate in English. \\
\hline & 18 & I wanted to be recognized as being a good English speaker. \\
\hline & 5 & I thought it was important to teach English in a globalized world. \\
\hline & 10 & I thought it was wonderful to be able to teach English. \\
\hline & 11 & I have had lots of interest in foreign culture and people. \\
\hline & 12 & I thought it was enjoyable to teach students English. \\
\hline \multirow{4}{*}{ Factor 2} & 14 & $\begin{array}{l}\text { I thought that English teaching was a stable job that would support my } \\
\text { family. }\end{array}$ \\
\hline & 15 & $\begin{array}{l}\text { I thought it would be difficult to find another job other than as an English } \\
\text { teacher. }\end{array}$ \\
\hline & 16 & I thought I had a talent for teaching English. \\
\hline & 7 & $\begin{array}{l}\text { I thought that being an English teacher could be a lifelong career without } \\
\text { any sexual discrimination. }\end{array}$ \\
\hline \multirow{4}{*}{ Factor 3} & 2 & I wanted to help students. \\
\hline & 8 & I wanted to contribute to society. \\
\hline & 6 & I liked teaching. \\
\hline & 13 & I wanted to contribute to the English education of my country. \\
\hline \multirow{3}{*}{ Factor 4} & 1 & $\begin{array}{l}\text { My parents advised me that being an English teacher is a good job for both } \\
\text { men and women. }\end{array}$ \\
\hline & 3 & $\begin{array}{l}\text { My parents would have been disappointed if I hadn't chosen to become an } \\
\text { English teacher. }\end{array}$ \\
\hline & 9 & $\begin{array}{l}\text { I was afraid of choosing another career unrelated to my undergraduate } \\
\text { major. }\end{array}$ \\
\hline
\end{tabular}




\section{Demotivation}

\begin{tabular}{|c|c|c|}
\hline & No & Item \\
\hline \multirow{3}{*}{ Factor 1} & 5 & Students' bored and uninterested attitudes in English classes \\
\hline & 7 & A large number of students in a single English class \\
\hline & 8 & Few opportunities to teach English in autonomous and diverse ways \\
\hline \multirow{3}{*}{ Factor 2} & 6 & Uncooperative attitudes of principal or fellow English teachers \\
\hline & 4 & $\begin{array}{l}\text { Lack of supports or understanding in the school regarding English } \\
\text { education (e.g., classrooms only for English, English teaching materials } \\
\text { and aids, and English storybooks) }\end{array}$ \\
\hline & 2 & An excessive amount of administrative tasks besides teaching English \\
\hline \multirow{3}{*}{ Factor 3} & 3 & None or few adequate rewards for what I do at school \\
\hline & 9 & Excessive interference or expectations of parents \\
\hline & 1 & Lack of social recognition and respect for teachers \\
\hline
\end{tabular}

